\title{
Features of pedagogical activity in development of communicative universal learning actions in younger school students
}

\author{
Anastasia Sergeevna Ryleeva, ${ }^{1, *}$, Svetlana Vladimirovna Emanova ${ }^{1}$, Margarita Afanasyevna Sokolskaya ${ }^{2}$ and Elena \\ Alexandrovna Kazantseva ${ }^{2}$ \\ ${ }^{1}$ Candidate of Pedagogical Sciences, Associate Professor of the Department of Pedagogy and Methods of Humanities Education Kurgan \\ State University, 640000, Kurgan, Russia \\ ${ }^{2}$ Senior Lecturer at the Department of Pedagogy and Methods of Humanities Education Kurgan State University, 640000, Kurgan, \\ Russia
}

\begin{abstract}
Annotation. The low level of communicative competence of students is reflected in the increase in the number of children with high social and interpersonal anxiety. Cases of rejection and harassment of children by classmates, loneliness, hostility and aggression towards peers are increasing. In this regard, there are requirements for the professional competence of the teacher working with children of primary school age. The primary school teacher has a task to organize effective pedagogical activity and to aim it at education of children's' ability to cooperate and work in group, to be tolerant to various opinions, to be able to listen and hear the partner, to state the point of view on a problem freely, accurately and clearly.
\end{abstract}

\section{Introduction}

Currently, modern society requires a person who thinks freely and has a high level of communicative competence.

Universal learning activities mastering that enable each student to be independent learn to set goals and find ways to solve them, to be able to monitor and evaluate learning activities and their results provides great opportunities for this. One of the blocks of universal learning activities (hereinafter the ULA) contained in the FSES PGE does is communication activities. The level of development of communicative ULA affects the socialization and adaptation of the individual in society (look table 1).

Now more and more we can see an increase in the number of children with high social anxiety. There are cases of aggressive behaviour, hostility and rejection among peers.

In the literature you can find a classification of children with all sorts of communication disorders.

1. Children with disorders in the emotional and volitional sphere. They are distinguished by aggressiveness, lack of self-control skills, disinhibition.

2. Children with signs of giftedness, who have a lack of arbitrariness and high conflict due to an increased sense of perfectionism.

3. Children with kinesthetic representative system are highly vulnerable, prone to self-flagellation.

4. Children with the type of temperament melancholic, characterized by self-doubt, choleric, characterized by short temper and incontinence.
Table 1. Types of communicative universal learning activities

\begin{tabular}{|l|l|l|}
\hline 1 & $\begin{array}{l}\text { I.N. Agafonova, } \\
\text { I.A. Grishanova, } \\
\text { O.N. Mostovaya }\end{array}$ & $\begin{array}{l}\text { - educational cooperation with the } \\
\text { teacher and peers-definition of the } \\
\text { purpose, functions of participants, } \\
\text { ways of interaction; } \\
- \text { raising questions-initiative of } \\
\text { students and further interaction in } \\
\text { the search and collection of } \\
\text { information; } \\
- \text { conflict resolution-problem } \\
\text { definition, search and evaluation } \\
\text { of conflict resolution options, } \\
\text { decision-making on their } \\
\text { resolution; } \\
- \text { management of partner's } \\
\text { behavior-control, correction, } \\
\text { evaluation of partner's actions; } \\
\text { - the ability to fully and accurately } \\
\text { express their thoughts in } \\
\text { accordance with the objectives and } \\
\text { conditions of communication. }\end{array}$ \\
\hline 2 & $\begin{array}{l}\text { - communication as interaction; } \\
\text { - communication as cooperation; } \\
\text { - communication as a condition of } \\
\text { interiorization. }\end{array}$ \\
\hline
\end{tabular}

In connection with different groups of children with communication impairments, it is necessary to consider a model of pedagogical activity for the development of communicative ULA.

In our work we relied on the conceptual provisions of various theories: the theory of activity and development of personality (B. G. Ananyev, L. I. Bozhovich, A. N. Leontiev, S. L. Rubinstein, etc.); research reflection in 
educational activities of children (A. B. Vorontsov, B. V. Davydov, N. Ya. Saigushev, etc.); formation and development of universal educational activities (A. G. Asmolov, G. V. Burmenskaya, I. A. Volodarskaya, O. A. Karabanova, etc.).

The reliability of the results is provided by the reliance on modern achievements of psychological and pedagogical sciences; the choice of methods and techniques that are adequate to the subject and objectives of the study; the representativeness of the sample of surveyed primary school children; quantitative analysis of experimental data; the introduction of research results in educational practice.

Based on the provisions of the system-activity approach, taking into account the requirements of the new Federal state educational standard of primary general education, a model of pedagogical activity for the development of communicative universal educational actions in younger students and a model of formation of professional competence of primary school teachers for the development of communicative universal educational actions in younger students are developed.

The materials can be widely used in the practice of secondary schools and institutions of additional education, in the implementation of curricula and programs of primary education, as well as in the system of professional development of teachers.

In this study, an attempt is made to resolve the contradiction between the social order for the formation of a person ready to interact with other people and the lack of effective implementation of this order by teachers.

\section{Materials and methods}

The study was conducted on the basis of the secondary educational institution of Kurgan "Secondary school № 34". The study involved students of the 1 "a" class in the amount of 28 people, 12 of them girls and 16 boys.

The present study was conducted in three stages:

1. Search and preparatory stage consisted in an analysis of the literature on the research topic, the definition of goals, objectives, research hypothesis carried out, the selection of diagnostic methods taking into account age characteristics.

2. The main stage included conducting a diagnostic study, conducting an ascertaining experiment and developing a model of psychological and educational activities for the development of communicative ULA among younger schoolchildren.

3. Control - summarizing included the analysis and synthesis of the results of the study.

We used the following methods for diagnostics:

1. "Left and right sides" (Piaget technique).

Objective: to identify the level of formation of actions aimed at taking into account the position of the interlocutor.

2. "Mittens" (methodology G. A. Tsukerman).
Objective: to identify the level of formation of actions to harmonize efforts in the process of organizing and implementing cooperation (cooperation).

3. "Dictation Pattern" (G.A. Tsukerman technique).

Purpose: to identify the ability to highlighting and displaying in speech the essential guidelines of the action, as well as transmit (communicate) them to their partner, the planning and regulatory function of speech.

Below are the results of the initial level of development of communicative ULA in the surveyed first graders. The high level is $17 \%$, the average level is $50 \%$, the low level is $33 \%$.

In connection with the results obtained, it can be concluded that the need for purposeful work on the development of communicative ULA is necessary. For this purpose, we have developed a model of pedagogical activity for the development of communicative ULA in children of primary school age (table 2).In this regard, there are new requirements for the professional competence of teachers who carry out pedagogical activities in the conditions of the requirements of the Federal State Educational Standards of PGE for the development of communicative ULA among younger students. Below is a model of the formation of professional competence of a teacher in the development of communicative ULA among younger students (see table 3)

\section{Discussion, results and conclusions}

After the implementation of the model of pedagogical activity on the formation of communicative ECD in younger schoolchildren, we carried out a re-diagnosis in order to identify the effectiveness of the work done.

Table 4. Results of the comparison of the input and intermediate diagnostics on the formation of communicative universal educational actions of class 1 "a"

\begin{tabular}{|l|c|c|c|}
\hline & & \multicolumn{2}{|c|}{ Student percentage } \\
\hline \multirow{2}{*}{$\begin{array}{l}\text { Method } \\
\text { name }\end{array}$} & Level & $\begin{array}{c}\text { Input } \\
\text { diagnostics }\end{array}$ & $\begin{array}{c}\text { Intermediate } \\
\text { diagnosis }\end{array}$ \\
\hline \multirow{2}{*}{$\begin{array}{c}\text { Left and } \\
\text { right side }\end{array}$} & Tall & $22 \%$ & $33 \%$ \\
\cline { 2 - 4 } & $\begin{array}{c}\text { Avera } \\
\text { ge }\end{array}$ & $50 \%$ & $56 \%$ \\
\cline { 2 - 4 } & Low & $28 \%$ & $11 \%$ \\
\hline \multirow{3}{*}{ Mittens } & Tall & $22 \%$ & $33 \%$ \\
\cline { 2 - 4 } & $\begin{array}{l}\text { Avera } \\
\text { ge }\end{array}$ & $56 \%$ & $67 \%$ \\
\hline \multirow{2}{*}{$\begin{array}{c}\text { Dictation } \\
\text { pattern }\end{array}$} & Low & $22 \%$ & - \\
\cline { 2 - 4 } & Avera & $11 \%$ & $39 \%$ \\
\cline { 2 - 4 } & Le & $56 \%$ & $39 \%$ \\
\hline
\end{tabular}


Table 2. Model of educational activities for the development of communicative universal learning activities

\begin{tabular}{|c|c|c|c|}
\hline \multicolumn{4}{|c|}{ Purpose: development of social competence, ability to cooperate and build constructive interaction } \\
\hline \multicolumn{4}{|c|}{ Substantive process component } \\
\hline \multicolumn{4}{|c|}{ Levels: basic, variable } \\
\hline $\begin{array}{l}\text { Levels of manifestation of } \\
\text { communicative ULA }\end{array}$ & tall & average & low \\
\hline $\begin{array}{c}\text { The nature of the } \\
\text { interaction }\end{array}$ & $\begin{array}{l}\text { Joint-separate with the } \\
\text { dynamics of roles }\end{array}$ & Joint & Reproductive \\
\hline Mechanisms & Attraction & Identification & Stereotyping \\
\hline Methods & Problematic & Partial search & Explanatory illustrative \\
\hline Forms & $\begin{array}{l}\text { Role-playing game } \\
\text { Blitz tournament } \\
\text { Opinion exchange }\end{array}$ & $\begin{array}{l}\text { Heuristic conversation } \\
\text { Commented reading }\end{array}$ & $\begin{array}{c}\text { Story } \\
\text { Exercise on the model }\end{array}$ \\
\hline \multicolumn{4}{|c|}{ Evaluation component } \\
\hline \multicolumn{4}{|c|}{ Success criteria } \\
\hline $\begin{array}{c}\text { understanding the } \\
\text { possibility of different } \\
\text { positions and points of } \\
\text { view }\end{array}$ & $\begin{array}{l}\text { the ability of children to } \\
\text { negotiate, come to a common } \\
\text { decision, the ability to } \\
\text { convince, } \\
\text { argue }\end{array}$ & $\begin{array}{l}\text { emotional attitude to joint activities: } \\
\text { positive, neutral or negative }\end{array}$ & $\begin{array}{l}\text { ability to make statements clear to the } \\
\text { partner }\end{array}$ \\
\hline \multicolumn{4}{|c|}{ Pedagogical conditions } \\
\hline Subjective & Objective & \multicolumn{2}{|c|}{ Resource provision } \\
\hline positive motivation & $\begin{array}{l}\text { activation of children for } \\
\text { self-determination and self- } \\
\text { actualization within the } \\
\text { framework of the system- } \\
\text { activity and meta-subject } \\
\text { approach } \\
\end{array}$ & \multicolumn{2}{|c|}{$\begin{array}{l}\text { Regulatory } \\
\text { staffing } \\
\text { logistical }\end{array}$} \\
\hline \multicolumn{4}{|c|}{ Effective component } \\
\hline Communication skills & Communicative actions & Comm & cation skills \\
\hline
\end{tabular}

Table 3. Model of the formation of professional competence in the development of communicative ULA among younger students

\begin{tabular}{|c|c|c|c|c|c|}
\hline & \multicolumn{5}{|c|}{$\begin{array}{l}\text { Goal setting component } \\
\text { Purpose: formation of a high level of professional competence of teachers, ensuring success } \\
\text { implementation of the requirements of the Federal State Educational Standards }\end{array}$} \\
\hline \multicolumn{6}{|c|}{$\begin{array}{l}\text { Resource Support Component } \\
\end{array}$} \\
\hline \multicolumn{6}{|c|}{$\begin{array}{c}1 \text { Conditions to ensure the implementation of the requirements of the FSES PGE } \\
\text { (internal resources) }\end{array}$} \\
\hline $\begin{array}{l}\text { Regulatory } \\
\text { support }\end{array}$ & $\begin{array}{l}\text { Methodic } \\
\text { al } \\
\text { support }\end{array}$ & Staffing & \multicolumn{2}{|c|}{ Organizational support } & Logistical support \\
\hline \multicolumn{6}{|c|}{$\begin{array}{l}2 \text { Conditions for networking of the TOE } \\
\text { (external resources) }\end{array}$} \\
\hline $\begin{array}{c}\text { Online } \\
\text { community of } \\
\text { educators }\end{array}$ & \multicolumn{2}{|c|}{$\begin{array}{l}\text { Municipal, regional, regional, } \\
\text { federal innovation sites }\end{array}$} & $\begin{array}{l}\text { Creative groups of } \\
\text { teachers }\end{array}$ & $\begin{array}{l}\text { Methodical associations of } \\
\text { pedagogical workers }\end{array}$ & Distance courses \\
\hline \multicolumn{6}{|c|}{ The substantive and procedural component of the model } \\
\hline \multicolumn{3}{|c|}{$\begin{array}{l}\text { Principles of formation of professional } \\
\text { Competence of teachers: } \\
\text {-the principle of openness; } \\
\text { - the principle of flexibility; } \\
\text {-the principle of integration; } \\
\text { - the principle of continuity; } \\
\text { - principle of dialogue; } \\
\text { - principle of cooperation. }\end{array}$} & $\begin{array}{l}\text { Reflexive-creative } \\
\text { mechanism for the } \\
\text { implementation } \\
\text { of the model }\end{array}$ & \multicolumn{2}{|c|}{ Technologies of system-activity approach } \\
\hline \multicolumn{6}{|c|}{ Criterion-estimated component of the model } \\
\hline $\begin{array}{l}\text { momentum of } \\
\text { innovation } \\
\text { change }\end{array}$ & \multicolumn{2}{|c|}{ reflexivity } & $\begin{array}{l}\text { availability achievement } \\
\text { motivation }\end{array}$ & \multicolumn{2}{|c|}{ creative tension indicator } \\
\hline \multicolumn{6}{|c|}{ Effective component of the model } \\
\hline \multicolumn{6}{|c|}{$\begin{array}{l}\begin{array}{l}\text { Successful implementation of the requirements of the Federal State Educational Standards of the National Educational Establishment } \\
\text { for the development of communicative ULA among younger students }\end{array} \\
\end{array}$} \\
\hline
\end{tabular}


At a high level, $17 \%$, and after y - $28 \%$ of students. The average level was detected before the experiment in - 50\%, and after y - 61\%. The low level before the experiment was $33 \%$, after which it remained in $11 \%$ of children.

Diagnostics showed that as a result of the implementation of the model, the number of students who have developed a communicative ULA at a high and medium level has increased.

Thus, according to the results of a comparative analysis of the results of input and intermediate diagnostics of the level of formation of communicative ULA in 1 "a" class, it can be concluded that the work will be more effective if you use dialogical forms of verbal communication and jointly separate productive activities in teaching activities.

\section{References}

1. O.G. Mishanova, MSPH, Scientific and methodological support of the problem of pedagogical management of communicative education of younger schoolchildren, 146. (2012).

2. Great psychological encyclopedia. St. Petersburg: CGI "Print" Retrieved from: http://psychology.academic.ru/ (2016).

3. A.G. Asmolov, ME, How to design universal learning activities in elementary school. From action to thought: a manual for teachers, 160, (2013).

4. A.A. Maksimova, PS., The development of communicative skills of younger schoolchildren in role-playing games, 1, 30-34. (2015).

5. GEF: Primary general education. SFT. Retrieved from: http://standart.edu.ru/ (2012)

6. A.G. Asmolov, G.V.Burmenskaya, I.A. Volodarskaya, O.A. Karabanova, S.V. Molchanov, N.G. Salmina, NPJ, Designing universal learning activities in high school, 1 (5), 104-110 (2011).

7. A.I. Balashov MEIaE.On the development of universal educational activities, 5, .69-73 (2009)

8. O.A. Drozdova, T.A. Smirnova PSQoTaP, Formation of communicative universal educational actions of younger schoolchildren as the leading result of training, '5 (59), 182-184 (2016).
9. V.S. Zhirkova YS. Methods and techniques for the formation of communicative universal learning activities in computer science lessons, 6, 88-91, Retrieved from: https://moluch.ru/archive/65/10822/ (2014).

10. A.K. Kolesnikov AM. Modern educational technologies for the future of the teacher [Modern educational technologies in the light of the requirements of the Federal State Educational Standards of Higher Vocational Education], 1, 34-38 (2013)

11. V.B. Lebedintsev FE., Individual educational programs of schoolchildren, 6, 189-197. (2010)

12. V.B. Lebedintsev PE, Individual training sessions in a small school, 9, 173-180 (2010).

13. V.B. Lebedintsev, N.M. Gorlenko. PE, Positions of teachers in the course of training in individual educational programs, 9, 224-231(2011).

14. N.A. Luzin, ESPBaA, Integration of modern technologies: an effective means of personalityoriented developmental education in elementary school, 10, 58-62 (2010).

15. N.N. Nagaychenko, T.V. Petuhova IPaPiE, Innovative programs and other educational projects, 2, 51-54 (2012).

16. V.A. Udovikova, St.PEB, Technologies for the formation of communicative UUD "Planning for educational cooperation” St. Petersburg, 4, 7-9, (2016)

17. M.O. Tkachenko,, S.V.NT, Salnikova Starting diagnosis of the level of formation of UUD at first graders, 6, 3-9 (2011)

18. A.V. Khutorskoy MEIE, Methods of designing and organizing metasubject educational activities of students, 2, 7-23 (2014)

19. N.V. Chertushkina St.PEB, Formation of communicative UUD at primary school lessons by means of social situations modeling, 4 7-9 (2016).

20. L.A. Shcherbacheva, S.G. Zheltova EaISM, ImplemEentation of the meta-subject approach in the educational process of the gymnasium, 6 12-16 (2014). 